\title{
Evaluation of total phenolic content and antioxidant activity of different solvent extracts of leaf material of Spathodea campanulata P. Beauv. and investigation of their proliferation inhibition potential against EAC cell line
}

\author{
Shankar Sangeetha, Swaminathan Meenakshi, Srinivasan Akshaya, Vellingiri Vadivel*, Pemaiah Brindha \\ Centre for Advanced Research in Indian System of Medicine (CARISM), SASTRA University, Thanjavur, Tamilnadu, India .
}

\section{ARTICLE INFO \\ Article history: \\ Received on: 01/01/2016 \\ Revised on: 03/03/2016 \\ Accepted on: 24/05/2016 \\ Available online: 26/09/2016 \\ Key words: \\ Spathodea campanulata; \\ Total phenols; Antioxidant; \\ Anticancer.}

\begin{abstract}
In the present study, antioxidant and anticancer activities of different solvent extracts of an Indian medicinal plant, Spathodea campanulata P. Beauv. (leaf) were investigated. Among the different extracts studied, 70\% ethanolic extract of $S$. campanulata leaf registered high antioxidant activity in terms of phosphomolybdate reducing power (955 FAEA), radical scavenging activity against DPPH (84.67\%), superoxide (72.69\%), hydrogen peroxide $(83.20 \%)$ and hydroxyl radicals $(70 \%)$, when compared to ethyl acetate and chloroform extracts. Further, the ethanolic extract illustrated remarkable anticancer activity against EAC cell line $(85 \%)$ when compared to ethyl acetate and chloroform extracts. Ethanol extract showed higher level of total phenolic concentration (9.21 mg FAE/L), which is correlated with the maximum antioxidant activity exhibited by this extract. Due to remarkable antioxidant and anticancer properties, the ethanolic extract of $S$. campanulata leaf could be considered as a natural source of plant based drug to prevent / treat oxidative stress induced diseases such as cancer.
\end{abstract}

\section{INTRODUCTION}

Spathodea campanulata P. Beauv. is commonly known as flame of the forest. This tree is native to the tropical dry forests of Africa but is growing extensively as an ornamental tree throughout the tropics and is much appreciated for its very showy reddish-orange or crimson coloured flowers. The Siddha / Tamil name of this species is Patadi and in folk it is popularly called as Ruugatuuraa. It is very commonly found and planted in the gardens, South Tamilnadu. It is a large tree that can reach $50 \mathrm{ft}$ in height. The pinnate leaves grow to $40 \mathrm{~cm}$ long and they are bronze in colour when young, turning deep glossy-green at maturity. The plant has also been used traditionally to treat convulsion and epilepsy (Ilodigwe et al., 2010).

\footnotetext{
* Corresponding Author

Vellingiri Vadivel, Centre for Advanced Research in Indian System of Medicine (CARISM), SASTRA University, Thanjavur, Tamilnadu, India Emai:vadivel@ carism.sastra.edu
}

In Laos, Cambodia and Vietnam, the flowers of this plant are used to heal ulcer (Rojas et al., 2006). In India, the stem bark preparations are employed against swollen cheeks, enemas, fungus skin diseases, herpes, stomach-ache and diarrhoea (Adriana et al., 2007). Traditionally the seeds, bark and leaves of this plant are used for cleaning of new born babies in many Indian villages. Anti-malarial, antioxidant, mulluscicidal, hepatoprotective, and nephroprotective activities of different parts of $S$. campanulata were proved scientifically (Shanmukha et al., 2010; Akharaiyi et al., 2012; Heim et al., 2012; Dadzeasah and Ansah, 2013). Stem bark has displayed hypoglycemic, anti-malarial, laxative, antiseptic and anti-HIV activities (Choudhury et al., 2011). Leaves have been reported to possess anti-plasmodial, analgesic, antimicrobial and anti-inflammatory properties (Kowti et al., 2010; Kowti et al., 2011; Sonibare and Osiyemi, 2012). Anti-leishmanial and mosquitocidial activities of $S$. campanulata leaf extract were investigated (Aarthi and Murugan, 2010; Karthika Devi et al., 2013; Dadzeasah and Ansah, 2013). 
Study of acute and sub chronic toxicity of $S$. campanulata leaf extract revealed its safety (Coolborn et al., 2012). The chemical and botanical characteristics of $S$. campanulata bark have been studied (Sonibare and Osiyemi, 2012; Brindha et al., 2012; Pulipati et al., 2013). Even though some reports are available on the medicinal properties of $S$. campanulata, there is no detailed investigation about its antioxidant and anticancer effects. Hence, the present study was carried out with a view to evaluate the antioxidant and anticancer potentials of different solvent extracts of Spathodea campanulata leaf.

\section{MATERIALS AND METHODS}

\section{Extract preparation}

The leaf material of Spathodea campanulata (500 g) was collected from SASTRA University campus, Thanjavur, Tamilnadu. All leaf materials were shade dried and powdered into $1 \mathrm{~mm}$ particle size using a lab mill. For extraction of phytochemical compounds from plant materials, different solvents such as chloroform (100\%), ethyl acetate (100\%) and ethanol $(70 \%)$ were used. Powdered leaf material (100 g) was taken in $1000 \mathrm{ml}$ beaker and $500 \mathrm{ml}$ of each solvent was added separately and kept at room temperature for $48 \mathrm{~h}$. Then the contents were filtered and the filtrate volume was noted. The filtrate was then allowed to evaporate at room temperature and the remaining residue weight was recorded. The dried extract was re-constituted with respective solvent at $1 \mathrm{mg} / \mathrm{ml}$ ratio and used for further experiments. Throughout the experimental period, the extracts were maintained at refrigerated condition and they brought to room temperature before $2 \mathrm{~h}$ of each experiment.

\section{Antioxidant activity \\ Phosphomolybdate assay}

The antioxidant activity of extracts was evaluated according to the method of Prieto et al. (1999). An aliquot of 100 $\mu \mathrm{l}$ of extract was combined with $1 \mathrm{ml}$ of reagent solution $(0.6 \mathrm{M}$ sulphuric acid, $28 \mathrm{mM}$ sodium phosphate, and $4 \mathrm{mM}$ ammonium molybdate) in a screw-capped vial. The vials were closed and incubated in a water bath at $95^{\circ} \mathrm{C}$ for $90 \mathrm{~min}$. After the samples had cooled to room temperature, the absorbance of the mixture was measured at $695 \mathrm{~nm}$ against a blank. The results expressed as ascorbic acid equivalent antioxidant activity.

\section{Ferric reducing power}

The reducing power of extract was determined according to the method of Oyaizu (1986). Samples $(2.5 \mathrm{ml})$ in phosphate buffer $(2.5 \mathrm{ml}, 0.2 \mathrm{M}, \mathrm{pH}$ 6.6) were added to potassium ferricyanide $(2.5 \mathrm{ml}, 1.0 \%)$ and the mixture was incubated at $50^{\circ} \mathrm{C}$ for $20 \mathrm{~min}$. Trichloroacetic acid $(2.5 \mathrm{ml}, 10 \%)$ was added, and the mixture was centrifuged at $650 \mathrm{x} \mathrm{g}$ $(\mathrm{rpm})$ for $10 \mathrm{~min}$. The supernatant $(5.0 \mathrm{ml})$ was mixed with ferric chloride $(5.0 \mathrm{ml}, 0.1 \%)$, and then the absorbance was read spectrophotometrically at $700 \mathrm{~nm}$. Based on the absorbency value, the ferric reducing power of extract was expressed.

\section{DPPH radical scavenging activity}

The DPPH radical scavenging activity was analyzed for each by following Sanchez-Moreno et al. (1998) method. The extract $(100 \mu \mathrm{l})$ was added to $3.9 \mathrm{ml}$ of DPPH solution $(0.025 \mathrm{~g} / \mathrm{L})$ and the reactants were incubated at $25^{\circ} \mathrm{C}$ for $30 \mathrm{~min}$. Different concentrations of ferulic acid was used as a positive control and ethanol was used instead of extract in blank. The decrease in absorbance was measured at $515 \mathrm{~nm}$ with a spectrophotometer. The radical scavenging activity of tested samples was calculated and expressed on percentage basis.

\section{Superoxide radical scavenging activity}

The capacity of extracts to scavenge the superoxide anion radical was measured according to the method described by Zhishen et al. (1999). The reaction mixture was prepared using $3 \mathrm{x}$ $10^{-6} \mathrm{M}$ riboflavin, $1 \times 10^{-2} \mathrm{M}$ methionine, $1 \times 10^{-4} \mathrm{M}$ nitroblue tetrozolium chloride and $0.1 \mathrm{mM}$ EDTA in phosphate buffered saline ( $\mathrm{pH} 7.4)$.

For the analysis, $3.0 \mathrm{ml}$ of the reaction mixture was taken with $100 \mu \mathrm{l}$ of extract in closed tubes and illuminated for $40 \mathrm{~min}$ under fluorescent lamp $(18 \mathrm{~W})$. The absorbance was then read at $560 \mathrm{~nm}$ against the un-illuminated reaction mixture. Results are expressed as superoxide radical scavenging activity on percentage basis.

\section{Hydrogen peroxide scavenging activity}

The effect of extract on hydrogen peroxide was analyzed according to the method proposed by Ruch et al. (1989). The extract (100 microliter) was mixed with $5 \mathrm{ml}$ of $45 \mathrm{mM}$ hydrogen peroxide solution in $0.1 \mathrm{M}$ phosphate buffer ( $\mathrm{pH} 7.4)$. The reaction mixture was vortexed and incubated for $30 \mathrm{~min}$ at room temperature and then the absorbency was measured at $230 \mathrm{~nm}$. The extract with phosphate buffer is used as a blank and the level of hydrogen peroxide remaining in the solution was calculated using a calibration curve. The hydrogen peroxide inhibition effect of extract was calculated and expressed on percentage basis.

\section{Hydroxyl radical scavenging activity}

The hydroxyl radical quenching activity of extracts was evaluated according to the method of Hagerman et al. (1998). The reaction mixture consists of $10 \mathrm{mM}$ phosphate buffer $(\mathrm{pH} 7.4), 2.8$ mM Deoxyribose, $2.8 \mathrm{mM} \mathrm{H} 2 \mathrm{O} 2,0.025 \mathrm{mM} \mathrm{FeCl3}, 0.1 \mathrm{mM}$ EDTA and $0.1 \mathrm{mM}$ ascorbic acid in a total volume of $3 \mathrm{ml}$. With the reaction mixture, 100 microliter of extract was added and incubated at $37^{\circ} \mathrm{C}$ for $15 \mathrm{~min}$.

Then the reaction was terminated by the addition of $1 \mathrm{ml}$ of $2.5 \%$ ice-cold TCA and $1 \%$ TBA. The reactants were mixed well and heated at $90 \mathrm{C}$ for $15 \mathrm{~min}$ in a water bath and cooled to room temperature. The chromogen was extracted with 1-butanol and absorbency was measured at $530 \mathrm{~nm}$. Based on absorbency value, the hydroxyl radical scavenging activity of extracts was calculated and expressed on percentage basis. 


\section{Anticancer activity}

The Ehrlich Ascites Carcinoma (EAC) cells were obtained from Swiss mice after 15 days of induction in the Central Animal Facility, SASTRA University, Thanjavur. The peritoneal fluid containing EAC cells was collected aseptically using a $5 \mathrm{ml}$ syringe and cultured in Dulbecco's modified Eagle's medium (DMEM) containing $10 \%$ fetal bovine serum (FBS) with penicillin $(100 \mu \mathrm{g} / \mathrm{ml})$ and streptomycin $(100 \mu \mathrm{g} / \mathrm{ml})$ at $37^{\circ} \mathrm{C}$. The cells were dispersed in a 96 well plate with a cell count of 9000 cells per well. Then the extracts of $S$. campanulata leaf were added at different concentrations (1000, 500, 250, 100, 50, 25 and 10 $\mu \mathrm{g} / \mathrm{ml}$ ) and then again incubated for $24 \mathrm{~h}$ in $\mathrm{CO}_{2}$ incubator with $5 \% \mathrm{CO}_{2}$. The cells grown in medium without plant extract were considered as control. At the end, the medium was discarded, cells are washed with PBS and then $20 \mu \mathrm{l}$ of MTT reagent (3,4,5dimethyl thiazol-2-yl 2,5 di phenyl tetrazolium bromide) was added in each well and incubated for $6 \mathrm{~h}$ at $37^{\circ} \mathrm{C}$ in a water bath according to the method of Scudiero et al. (1988). Then $150 \mu \mathrm{l}$ of acidic isopropanol was added and shaken for $30 \mathrm{~min}$ on a plate shaker under dark. The absorbance was measured at $540 \mathrm{~nm}$ in a micro-plate reader and the percentage growth inhibition was calculated using the following formula: (Absorbance of control Absorbance of treated / Absorbance of control) x 100.

\section{Quantification of phytochemicals}

The total phenolic content of different extracts of $S$. campanulata leaf was analyzed using Folin-Ciocalteu reagent method with some modifications (Singleton et al., 1999). Total alkaloid content was estimated according to the method described in Indian Pharmacopoeia (2014. Total flavonoid content was determined using aluminium chloride according to the method of Zhishen et al. (1999) using quercetin as a standard. The extract was investigated for tannins content according to the method of Rajpal (2011).

\section{RESULTS AND DISCUSSION}

\section{Antioxidant activity}

Reactive oxygen species (ROS) are produced in the body as a result of incomplete reduction of oxygen during oxidative phosphorylation (Nathan, 2003). Free radicals could attack DNA and results in mutation and cancer (Perse, 2013). It also can react with proteins, carbohydrates and lipids and plays a significant role in the pathogenesis of numerous disorders and patho-physiological processes including cardiovascular diseases, diabetes, and cancer (Federico et al., 2007). Oxidative stress occurs, when the system loses its ability to neutralise the excessively produced reactive species. The redox homeostasis, i.e. the balance between the free radicals and antioxidants is necessary for maintaining good health. This balance is maintained by a number of antioxidants (vitamin $\mathrm{E}$ and ascorbic acid) and enzymes like catalase, glutathione peroxidise, glutathione-S-transferase, superoxide dismutase etc. Under severe conditions, above-mentioned antioxidant system is not sufficient to prevent the oxidative stress. Hence, intake of external anti-oxidants is necessary for maintaining homeostasis in the body. When we are looking for natural source of antioxidants, the medicinal plants from Bignonaceae family received attention, because some of their members are well known for medicinal effects (Rahmatullah et al., 2014). In this connection, in the present work, $S$. campanulata leaf is investigated for its antioxidant activity and the results are shown in Figure 1.

The reducing capacity of a compound may serve as a significant indicator of its potential antioxidant. Figure 1-A reveals the phosphomolybdate reducing power of different solvent extracts of $S$. campanulata. Among the investigated extracts, the ethanol extract of registered higher level of reducing power (952 FAEA), which is followed by ethyl acetate (740 FAEA) and chloroform extracts (198 FAEA). In ferric reducing assay, Fe (III) is reduced to $\mathrm{Fe}$ (II) by the antioxidant compound through electron transfer. The reduced Fe (II) forms the Pearl's blue complex, which can be measured at $700 \mathrm{~nm}$. In contrast to other assays, it can be seen that the chloroform extract of $S$. campanulata leaf (0.73 Abs units) have high antioxidant power on examining ferric reducing power (Figure 1-B). This might be due to the fact that some phytochemical component of $S$. campanulata leaf soluble in chloroform has strong ferric reducing power. On performing the DPPH radical scavenging assay for the different extracts, higher level of antioxidant activity was noted in ethanol extract of $S$. campanulata leaf (84.67\%) (Figure 1-C). The evaluation of the antioxidant power by DPPH radical scavenging activity has been widely in use for different plant extracts. The decrease in absorbency at $515 \mathrm{~nm}$ may be due to the reaction between phytochemicals and DPPH, which indicates the antioxidant power. The superoxide radical scavenging activity of samples was investigated by generating superoxide through photo-induced reduction of riboflavin, which can generate superoxide radical in the presence of methionine. The superoxide scavenging activity of various extracts of $S$. campanulata was shown in the Figure 1-D, which revealed that the ethanolic extract had very high radical scavenging power $(72.69 \%)$, which is followed by ethyl acetate $(51.03 \%)$ and chloroform extracts $(11.28 \%)$.

The effect of different solvent extracts on the hydrogen peroxide inhibition was illustrated in the Figure 1-E. The results revealed that the ethanolic $(83.20 \%)$ and ethyl acetate $(80.05 \%)$ extracts of $S$. campanulata leaf have higher level of hydrogen peroxide inhibition activity when compared to chloroform extract (28.73\%). Hydrogen peroxide itself is not very reactive, but it can sometimes be toxic to cell because it may give rise to hydroxyl radical in the cells. Thus, removing hydrogen peroxide is very important for protection of cellular system. Hydroxyl radical inhibition assay performed for different solvent extracts of $S$. campanulata indicates that the ethanolic extract was more effective in scavenging the hydroxyl radicals in $S$. campanulata $(70.16 \%)$ when compared to ethyl acetate $(55.41 \%)$ and chloroform extracts $(39.51 \%$ ) (Figure $1-\mathrm{F})$. OH radicals may attack various biomolecules including proteins, lipids, and DNA and cause oxidative damage to the cellular components and hence it is considered to be biologically dangerous free radical. 

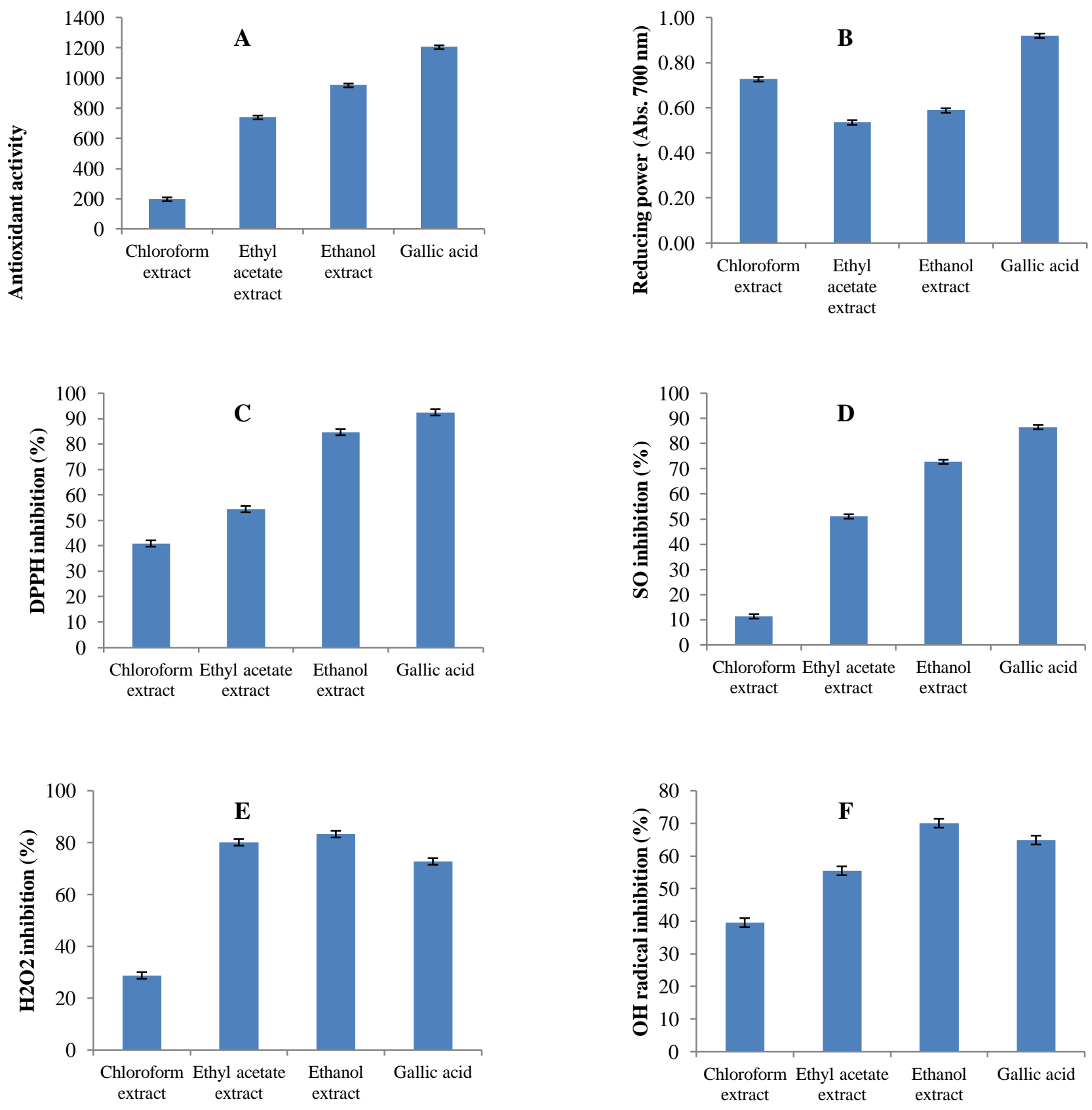

Fig. 1: Antioxidant activity of different solvent extracts of $S$. campanulata leaf. (A) Phosphomolybdate reducing power; (B) Ferric reducing power; (C) DPPH radical scavenging activity; (D) Superoxide scavenging activity; (E) H2O2 inhibition capacity (F) Hydroxyl radical inhibition activity

\section{Anticancer activity}

Cancer is often associated with increased risk of death and the toxic side effects caused by the modern medicine, many cancer patients seek alternative and complementary methods of treatment such as usage of phytomedicine (Kim and Park, 2002). At present chemotherapy is considered as the most efficient approach for cancer treatment. Even though it significantly improves symptoms and the quality of life of cancer patients, only modest increase in survival rate can be achieved. As a palliative care, many cancer patients use herbal therapies. Medicinal plants are well known for their free radical scavenging and antioxidant activities (Agarwal et al., 2001). Free radical attack results in the oxidative damage of various biomolecules including lipids, proteins and DNA. The Damage caused in DNA leads to mutation or cancer, which is the most dangerous effect in human beings. Plants contain phytochemicals with strong antioxidant activities which may prevent and control cancer and other diseases by protecting the cells from the deleterious effects of the free radicals. Now-a-days researchers are focusing their research towards the development of an eco-friendly anticancer drug from plant sources, which resulted in newer chemotherapeutic agents such as paclitaxel, vincristine, podophyllotoxin and camptothecin. 


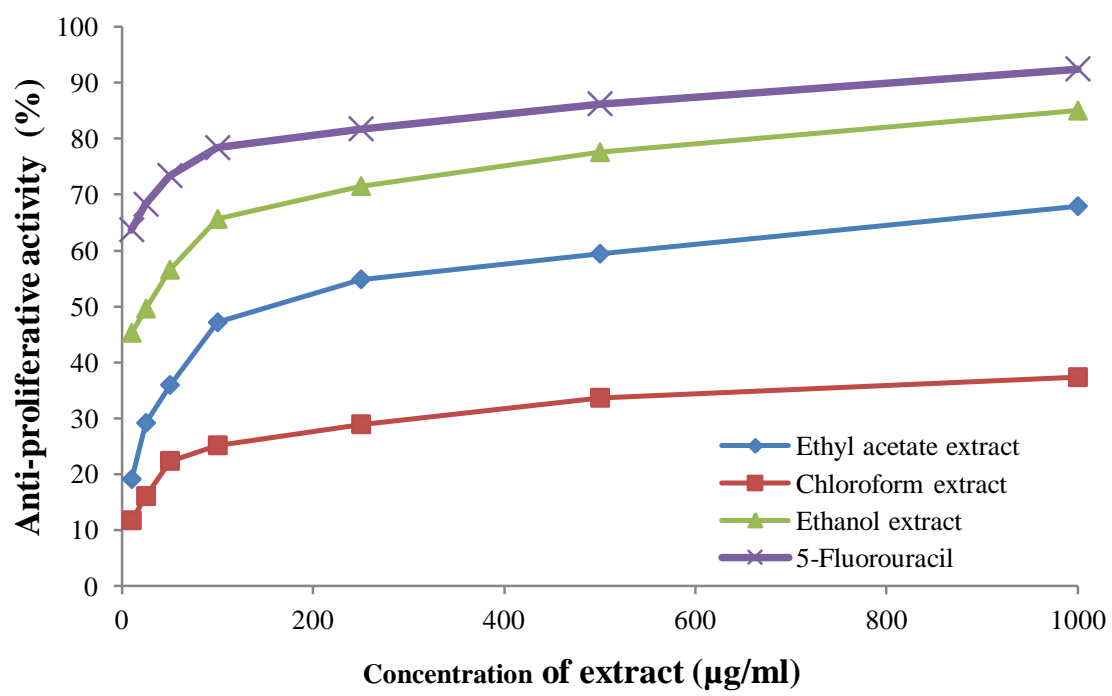

Fig. 2: Proliferation inhibition potential of different extracts of Spathodea campanulata against EAC cell line.

In the present study, different solvent extracts of $S$. campanulata were screened for anticancer potential against Ehrlich Ascites Carcinoma cell lines employing MTT assay with a view to develop a natural and safe anticancer drug. Among the solvent extracts used, $70 \%$ ethanolic extract of revealed remarkable level of anticancer effect $(84.97 \%$ at a $1000 \mu \mathrm{g} / \mathrm{ml})$ (Figure 2). Cytotoxicity was found to be maximum even at a very low concentration $(56 \%$ at $50 \mu \mathrm{g} / \mathrm{ml})$. The death of the cells caused by the test drug might be due to the loss of mitochondria which is one of the hallmarks of the apoptosis pathway (Christopher, 1992). From the MTT assay, it is evident that the cytotoxicity of the extracts against EAC cell line was dose dependent. Based on the results obtained from the present study, the ethanolic extract of $S$. campanulata was found to be more effective in controlling the growth of EAC cell lines when compared to other extracts. Hence, ethanolic extract of $S$. campanulata leaf could be considered as a source of potential anticancer drug and further in vivo models must be used to establish its anticancer efficacy.

\section{Phytochemical compounds}

Various phytochemical compounds such as alkaloids, flavonoids, tannins and total phenols were found to present in appreciable quantity in S. campanulata extracts (Figure 3). Among the different extracts, ethanolic extract contained higher levels of alkaloids (1.42 mg/L), flavonoids (7.36 mg QE/L) and total phenols (9.21 mg GAE/L), while ethyl acetate extract revealed higher content of tannins $(1.56 \mathrm{mg} / \mathrm{L})$. Since, the polyphenols are proven to be responsible for the antioxidant effect of plant drugs, the total phenolic content of $S$. campanulata was quantified by Folin-Ciocaltue reagent method. The analysis of total phenolic concentration in the presently investigated samples revealed higher level of total phenolics in ethanolic extract of $S$. campanulata leaf (9.21 mg FAE/L), which is followed by ethyl acetate $(8.42 \mathrm{mg}$ FAE/L) and chloroform extracts (1.24 mg FAE/L) (Figure 3). These results indicate the polyphenols present in S. campanulata might be of high polar in nature and hence, ethanol could be the suitable solvent to recover them effectively. Further, higher concentration of total phenols in ethanolic extract might be responsible for the maximum level of antioxidant and anticancer activities exhibited by the ethanolic extract of $S$. campanulata leaf when compared to other extracts.

Previous studies performed with different parts of $S$. campanulata, including stem barks, leaves, flowers and fruits revealed the presence of various phenolic compounds (Ngouela et al., 1990).

The leaves have furnished spathodol, caffeic acid and flavonoids (Ngouela et al., 1991; El-Hela, 2001; Gouda, 2009a). Banerjee and Bratati (2001) showed the presence of anthocyanins in flowers of $S$. campanulata. Presence of phenolic ester (methyl p-hydroxy benzoate), phenolic acids (phydroxy benzoic, caffeic, ferulic, gallic, protocatechuic, chlorogenic and p-coumaric), flavonoids (kaempferol 3-O-glucoside, quercetin 3-methyl ether, 8-methoxy kaempferol 3-O-glucoside, apigenin, luteolin, diosmetin, dihydrokaempferol-7-O-(2"-O-formyl)-ß-Dglucopyranoside, quercetin, quercetin-3-Oglucoside and quercetin7-O-glucoside) (Gormann et al., 2006; Subramanian et al., 1973) and iridoids in the roots and leaves were reported (Poser et al., 2000; Gouda, 2009b). Extraction process was optimized for the phytochemical investigation in $S$. campanulata flowers (Zaheer et al., 2011).

HPLC fingerprinting of ethanolic extract of this plant revealed the presence of gallic acid, catechol, coumarin and quercetin (Boniface et al., 2014). Hence, the previous literature data on phytochemical composition of $S$. campanulata also supported the presence of various polyphenolic compounds in the leaf sample, which is in good agreement with the total phenolic content reported in the present study. Thus, the polyphenolic compounds present in $S$. campanulata leaf might be responsible for the observed antioxidant and anticancer activities as the positive relationship was shown by ethanolic extract. 

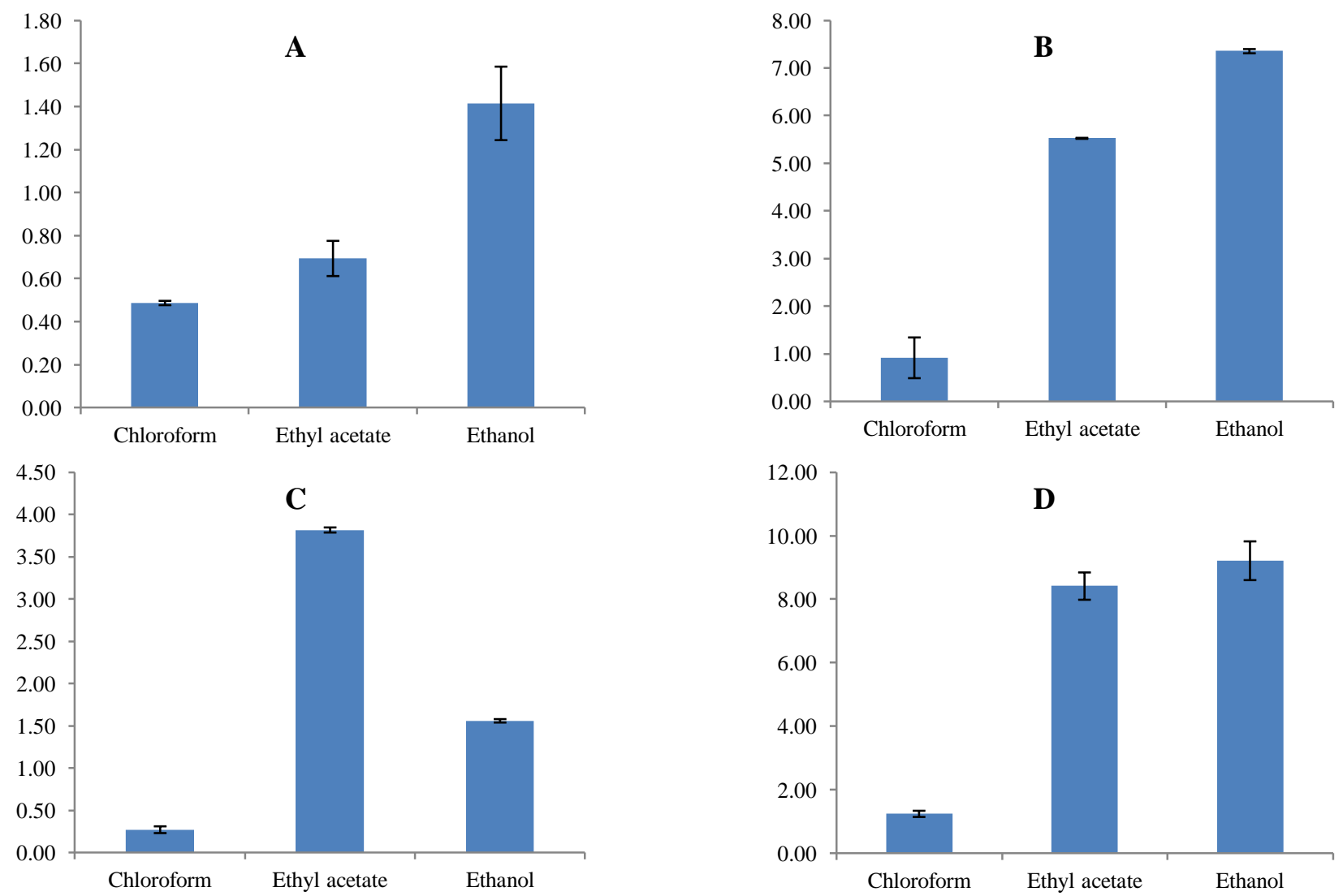

Fig. 3: Phytochemical constituents in different solvent extracts of $S$. campanulata leaf.

(A) Alkaloid concentration (mg/L), (B) Flavonoid concentration (mg QE/L), (C) Tannin concentration (mg/L) and Total phenolic concentration (mg GAE/L)

\section{CONCLUSION}

The results of the present investigation revealed the presence of remarkable antioxidant and anticancer properties in the ethanolic extract of S. campanulata leaf. Ethanol $(70 \%)$ could be the suitable solvent to recover the polyphenolic compounds with high antioxidant and anticancer potentials from $S$. campanulata leaf. Since the ethanolic extract of this medicinal plant having good antioxidant and anticancer properties, they might prevent the oxidative stress induced diseases like cancer, which should be investigated using suitable animal models in future. Exploring the medicinal value of such indigenous plants to combat the chronic diseases will be beneficial for the human society.

Financial support and sponsorship: One of the authors (Vellingiri Vadivel) is thankful to the management and administrative authorities of SASTRA University, Thanjavur, Tamilnadu for the sanction of TRR research fund to conduct this research project.

Conflict of Interests: There are no conflicts of interest.

\section{REFERENCES}

Aarthi N, Murugan K. Larvicidal and smoke repellent activities of Spathodea campanulata P. Beauv. against the malarial vector Anopheles stephensilis (Diptera: Culicidae). J Phytol, 2010; 2: 61-69.
Adriana P, Jurandir PP, Dalva TF, Noemia KI, Raimundo BF. Iridoid glucose and antifungal phenolic compounds from Spathodea campanulata roots. Cien Agrar, 2007; 28: 251-256.

Agarwal SK, Chatterjee S, Misra SK. Immune potentiating activity of a poly herbal formulation 'Immu-21'. Phytomedica, 2001; 2: 1-22.

Akharaiyi FC, Boboye B, Adetuyi FC. Antibacterial, phytochemical and antioxidant activities of the leaf extracts of Gliricidia sepium and Spathodea campanulata. World App Sci J, 2012; 16: 523-530.

Banerjee A, Bratati DE. Anthocyanins in some flowers of West Bengal. J Med Arom Plant Sci, 2001; 23: 600-604.

Boniface PK, Singh M, Pal A. HPLC-DAD fingerprinting of ethanol extracts from Conyza sumatrensis and Spathodea campanulata and their additive effect in Plasmodium berghei K173 infected mice. Am J Phytomed Clin Ther, 2014; 2: 660-669.

Brindha P, Nagarajan A, Saralla RP, Narendran R, Sridharan K. A study on chemical and botanical standards of a traditional drug source Spathodea campanulata Beauv. Int J Pharm Pharm Sci, 2012; 4: 157-160.

Chenganmal M, Yamalai M. Determination of bioactive components in Azadirachta indica flowers using GC-MS analysis. Asian J Plant Sci Res, 2015; 5: 61-65.

Choudhury S, Datta S, Talukdar AD, Choudhury MD. Phytochemistry of the family Bignoniaceae - A review. Assam Uni J Sci Technol Biol Env Sci, 2011; 7: 145-150.

Christopher SP. The significance of spontaneous and induced apoptosis in gastrointestinal tract of mice. Cancer Metstat Rev, 1992; 11: 179-195.

Dadzeasah PE, Ansah C. Spathodea campanulata extract attenuates acetaminophen-induced hepatic injury in mice. Int J Pharm Sci Drug Res, 2013; 5: 158-164.

El-Hela AA. A new iridoid glucoside from Spathodea campanulata Beauv. leaves. Al-Azhar J Pharm Sci, 2001; 27: 115-120. 
Federico A, Morgillo F, Tuccillo C, Ciardiello F, Loguercio C. Chronic inflammation and oxidative stress in human carcinogenesis. Int $\mathrm{J}$ Cancer, 2007; 121: 2381-2386.

Gormann R, Kaloga M, Kolodziej H. Novel flavonoids from leaf extracts of Markhamia acuminata and Spathodea campanulata. Plant Med, 2006; 72: 35 .

Gouda YG. Flavonoids and phenylpropanoids from Spathodea campanulata P. Beauvais leaves. Bull Pharm Sci, 2009 a; 32: 301-309.

Gouda YG. Iridoids from Spathodea campanulata P. Beauvais leaves. Nat Prod Comm, 2009 b; 4: 753-756.

Hagerman AE, Ried KM, Jones GA, Sovik KN, Ritchard NT, Hartzfeld PW, Riechel TL. High molecular weight plant polyphenolics (Tannins) as biological antioxidants. J Agric Food Chem, 1998; 46: 18871892.

Heim SC, Guarnier FA, Ferreira DT, Braz-Filho R, Cecchini R, Cecchini AL. Antioxidant activity of Spathodea campanulata (Bignoneaceae) extracts. Rev Bras Plant Med. Botucatu, 2012; 14: 287-92.

Ilodigwe EE, Akah PA, Nworu CS. Anticonvulsant activity of ethanol leaf extract of Spathodea campanulata (Bignoniaceae). J Med Food, 2010; 13: 827-833.

Indian Pharmacopoeia, Vol. 7, Published by Ministry of Health and Family Welfare, Government of India, 2014; p. 3185.

Karthika Devi K, Mohanraj RS, Dhanakkodi B. Mosquitocidial activities of Spathodea campanulata methanolic leaf extract against the dengue vector Aedes aegypti. Asian J Plant Sci Res, 2013; 3: 138-149.

Kim J, Park EJ. Cytotoxic anticancer candidates from natural resources. Cur Med Chem Anticancer Agent, 2002; 20: 485-537.

Kowti R, Harsha R, Ahmed MG, Hareesh AR, Thammanna Gowda SS, Dinesha R, Satish Kumar BP, Irfan Ali M. Antimicrobial activity of ethanol extract of leaf and flower of Spathodea campanulata P. Beauv. Res J Pharm Biol Chem Sci, 2010; 1: 691-698.

Kowti R, Joshi V, Dabadi P, Thammanna Gowda SS, Satish BP, Dinesha R. Antioxidant activity of Spathodea campanulata in prevention of TBOOH and $\mathrm{H} 2 \mathrm{O} 2$ induced DNA damage. Int J Cur Pharm Res, 2011; 3: 87-89.

Kumaresan M, Palanisamy PN, Kumar PE. Chemical investigation of flower of Spathodea campanulata by GC-MS. J Nat Prod Plant Resour, 2011; 1: 14-17.

Mbosso EJT, Ngouela S, Nguedia JCA, Penlap V, Rohmer M, Tsamo E. Spathoside, a cerebroside and other antibacterial constituents of the stem bark of Spathodea campanulata. Nat Prod Res, 2008; 22: 296304.

Nathan C. Specificity of a third kind: Reactive oxygen and nitrogen intermediates in cell signalling. J Clin Invest, 2003; 111: 769778

Nazif NM. Phytochemical and antioxidant activity of Spathodea campanulata P. Beauvois. growing in Egypt. Nat Prod Sci, 2007;13:11-16.

Ngouela S, Nyasse B, Tsamo E, Sondengam BL, Connolly JD. Spathodic acid: a triterpene acid from the stem bark of Spathodea campanulata. Phytochem, 1990; 29: 3959-3961.

Ngouela S, Tsamo E, Sondengam BL, Connolly JD. Spathodol A new polyhydroxysterol from the leaves of Spathodea campanulata. J Nat Prod, 1991; 54: 873-876.

Ngouela S, Tsamo E, Sondengam BL. Extractives from Bignoniaceae: Constituents of the stem bark of Spathodea campanulata. Planta Med, 1988; 54, 476.

Oyaizu M. Studies on products of browning reactions: Antioxidant activities of products of browning reaction prepared from glucosamine. Jap J Nutr, 1986; 44: 307-315.

Parthipan B, Suky MGT, Mohan VR. GC-MS Analysis of phytocomponents in Pleiospermium alatum (Wall. ex Wight \& Arn.) Swingle (Rutaceae). J Pharmacog Phytochem, 2015; 4: 216-222.

Perse M. Oxidative stress in the pathogenesis of colorectal cancer: Cause or consequence? BioMed Res Int, 2013; Article ID 725710.

Poser GL, Schripsema J, Henriques AT, Jensen SR. The distribution of iridoids in Bignoniaceae. Biochem Sys Ecol,2000;28:351366.

Prieto P, Pineda M, Aguilar M. Spectrophotometric quantitation of antioxidant capacity through the formation of a phosphomolybdenum complex: Specific application to the determination of vitamin E. Anal Biochem, 1999; 269: 337-341.

Pulipati S, Hapsana Parveen SK, Kiran Babu R, Vagdevi G, Srinivasa Babu P. Pharmacognostical and physicochemical standardization of leaves of Spathodea Campanulata P. Beauv. J Pharmacog Phytochem, 2013; 2: 189-192.

Rahmatullah M, Samarrai W, Jahan R, Rahman S, Sharmin N, Miajee EU, Chowdhury MH, Bari S, Jamal F, Bashar ABMA, Azad AK, Ahsan S. An ethnomedicinal, pharmacological and phytochemical review of some Bignoniaceae family plants and a description of Bignoniaceae plants in folk medicinal uses in Bangladesh. Acta Pol Pharm, 2014; 66 : 83-88.

Rajpal V. Standardization of botanicals, testing and extraction methods of medicinal herbs, Vol. 2, Business Horizons Publisher, New Delhi, 2011, p. 542.

Rojas JJ, Ochoa VJ, Ocampo SA, Munoz JF. Screening for antimicrobial activity of ten medicinal plants used in Colombian folkloric medicine: A possible alternative in the treatment of nonnosocomial infections. BioMed Central Comp Alt Med, 2006; 6: 1-6.

Ruch RJ, Cheng SJ, Klaunig E. Prevention of cytotoxicity and inhibition of intercellular communication by anti-oxidant catechins isolated from Chineese green tea. Carcinogen, 1989; 10: 1003-1008.

Sanchez-Moreno C, Larrauri JA, Saura-Calixto FA. A procedure to measure the antiradical efficiency of polyphenols. J. Sci Food Agric, 1998; 76: 270-276.

Saxena S, Pant N, Jain DC, Bhakuni RS. Antimalarial agents from plant sources. Cur Sci, 2003; 85: 1314-1329.

Scogin R. Anthocyanins of the Bignoniaceae. Biochem Sys Ecol, 1980; 8: 273-276

Scudiero DA, Shoemaker RH, Paul KD. Evaluation of soluble terazolium formazan assay for cell growth and drug sensitivity in clusters using human and other tumor cell lines. Cancer Res, 1988; 48: 4827-4833.

Senthil Kumar M, Vinoth Kumar D, Saravana Kumar A, Aslam A, Shajahan A. The phytochemical constituents of Withania somnifera and Withania obtusifolia by GC-MS analysis. Int J Pharmacog Phytochem Res, 2011; 3: 31-34

Shanmukha I, Siddiq A, Kamlesh G, Khan M, Ramachandra Setty S. Antioxidant and nephroprotective activity of Spathodea campanulata bark against gentamycin induced nephrotoxicity. Pharmacol Online, 2010; 1: 666-675.

Singleton VL, Orthofer R, Lamuela-Raventos RM. Analysis of total phenols and other oxidation substrates and antioxidants by means of Folin-Ciocalteu reagent. Method Enzymol, 1999; 299: 152-178.

Sonibare MA, Osiyemi OA. Morphological and anatomical studies of two medicinal plants: Harrisonia abyssinica Oliv. (Simaroubaceae) and Spathodea campanulata P. Beauv. (Bignoniaceae) and their systematic significance. J Chem Pharm Res, 2012; 4: 800-807.

Subramanian SS, Sulochana N, Nagarajan S. Caffeic acid from the leaves of Spathodea campanulata. Cur Sci, 1973; 42: 403.

Zaheer Z, Paithankar AP, Deshpande SD, Khan S. Optimization of extraction process and phytochemical investigations of Spathodea campanulata flowers. Afr J Pharm Pharmacol, 2011; 5: 2226-2231.

Zhishen J, Mengcheng T, Jianming W. The determination of flavonoid contents on mulberry and their scavenging effects on superoxide radical. Food Chem, 1999; 64: 555-559.

\section{How to cite this article:}

Sangeetha S, Meenakshi S, Akshaya S, Vadivel V, Brindha P. Evaluation of total phenolic content and antioxidant activity of different solvent extracts of leaf material of Spathodea campanulata P. Beauv. and investigation of their proliferation inhibition potential against EAC cell line. J App Pharm Sci, 2016; 6 (09): 121-127. 